\title{
MODEL PENGEMBANGAN PROFESIONALSIME GURU BAHASA INGGRIS BERBASIS EVALUASI PROGRAM MUSYAWARAH GURU MATA PELAJARAN
}

\author{
Sumardi (arif_sumardi74@yahoo.co.id)
}

\begin{abstract}
This $R$ \& D-based study aims to (i) create a model of professional development of English Language Teacher (PDELT model), and (ii) identify the effectiveness of the model. The development procedure is based on the theory of Borg and Gall (1983), comprises 4 steps, namely (i) preliminary study, (ii) development of prototype, (iii) field test, and (iv) dissemination of results. Subjects were teachers of English Language as PDLET program participants, students involved, and 4 high school principals located in the district of Sragen, Central Java as represented public high school (SMAN) and Private High School. Results showed that the PDLET program should not rely on teacher training activities only, but should considered the non-training aspects, such as climate and working conditions in the school, group dynamics, and teacher's perception toward the program PDLET. Those aspects can create a conducive atmosphere that acts as a catalyst to improve the effectiveness of implementation model MGMP. The combination of training and educational activities simultaneously affect the change of teacher professionalism.
\end{abstract}

Keywords: English language teacher, professional development model

\begin{abstract}
ABSTRAK
Penelitian R \& D-base ini bertujuan untuk (i) menciptakan model pengembangan profesional guru Bahasa Inggris (PDELT model), dan (ii) mengidentifikasi efektivitas model. Prosedur pengembangan didasarkan pada teori Borg dan Gall (1983), terdiri dari 4 langkah, yaitu (i) studi pendahuluan, (ii) pengembangan prototipe, (iii) uji lapangan, dan (iv) diseminasi hasil. Subyek penelitian adalah guru Bahasa Inggris sebagai peserta program PDLET, siswa yang terlibat, dan 4 kepala sekolah tinggi yang terletak di distrik Sragen, Jawa Tengah yang diwakili sekolah menengah umum (SMAN) dan Sekolah Tinggi Swasta. Hasil penelitian menunjukkan bahwa program PDLET tidak harus bergantung pada kegiatan pelatihan guru saja, tetapi harus dianggap sebagai non-pelatihan aspek, seperti iklim dan kondisi kerja di sekolah, dinamika kelompok, dan persepsi guru terhadap PDLET program. Aspek-aspek dapat menciptakan suasana kondusif yang bertindak sebagai katalis untuk meningkatkan efektivitas pelaksanaan model MGMP. Kombinasi pelatihan dan kegiatan pendidikan secara simultan mempengaruhi perubahan profesionalisme guru.
\end{abstract}

Kata kunci: guru bahasa Inggris, model pengembangan profesional

Program musyawarah guru mata pelajaran (MGMP) merupakan wadah berkumpulnya para guru mata pelajaran sejenis secara kolaboratif dalam satu wilayah tertentu (kabupaten/kota) dalam rangka mengidentifikasi dan memecahkan masalah, menguji coba dan mengembangkan ide-ide baru dalam rangka peningkatan mutu pembelajaran. Forum ini dipercaya menjadi salah satu media efektif 
untuk membina profesionalisme guru dalam kerangka kegiatan oleh, dari dan untuk guru (Jalal, 2005:55). Pernyataan ini mengandung makna bahwa program MGMP merupakan sebuah program untuk mengembangkan inovasi, kreativitas, komunikasi, konsultasi, informasi, maupun koordinasi diantara sesama guru-guru mata pelajaran sejenis dalam rangka memperbaiki kualitas pembelajaran.

Fokus program MGMP adalah perbaikan kualitas pembelajaran yang dilakukan melalui berbagai aktivitas kolaboratif, misalnya membuat rencana kegiatan pembelajaran, membuat dan berlatih menggunakan alat/bahan pembelajaran, mendatangkan pakar, berlatih menggunakan pendekatan pembelajaran baru, membahas isu-isu pendidikan terbaru, bengkel kerja dan sebagainya (Depdiknas, 1996b:91). Selanjutnya UNESCO menyatakan pula bahwa pengembangan profesionalisme guru yang paling efektif di Indonesia adalah melalui forum MGMP, karena forum ini dapat digunakan sebagai sarana untuk meningkatkan kemampuan akademis guru yang meliputi kemampuan pedagogis, profesional, serta kemampuan untuk melakukan asesmen dan penulisan silabus (2006:29). Forum yang di desain oleh, dari, dan untuk guru ini diyakini mampu memberikan kontribusi dalam meningkatkan motivasi guru untuk lebih banyak belajar dan belajar banyak.

Kondisi kontradiktif justru diketahui bahwa implementasi program MGMP masih memiliki banyak kekurangan. Implementasi program MGMP bahasa Inggris telah berlangsung dalam kurun waktu yang cukup lama. Program tersebut telah melakukan berbagai aktivitas yang dimaksudkan untuk memperbaiki kualitas pembelajaran bahasa Inggris. Walaupun demikian, berdasarkan studi awal yang dilakukan oleh peneliti (2008) terhadap implementasi program MGMP bahasa Inggris Sekolah Menengah Atas (SMA) di kabupaten Sragen, ditemukan bahwa praktik pembelajaran yang dilakukan oleh guru-guru bahasa Inggris setelah berpartisipasi dalam program MGMP cenderung tidak berbeda dengan praktik pembelajaran yang dilakukan oleh guru-guru bahasa Inggris sebelum berpartisipasi dalam program MGMP bahasa Inggris. Senada dengan temuan ini, Sudarnoto didalam Sumardi (2012) menyatakan bahwa faktor yang menyebabkan ketidakefektifan MGMP itu muncul karena aktivitas MGMP tidak dilakukan secara koordinatif dan tidak dilakukan monitoring secara terprogram. Oleh karena itu, Sudarnoto menyarankan bahwa perlu ada upaya untuk merevitalisasi kelompok-kelompok MGMP secara terprogram oleh Dinas Pendidikan di setiap kabupaten/kota.

Menyadari kondisi, peran, dan fungsi program MGMP bahasa Inggris yang selama ini belum mampu secara efektif memperbaiki kualitas pembelajaran yang dilakukan oleh peserta, maka perlu dikembangkan model alternatif pengembangan profesionalisme guru bahasa Inggris. Model pengembangan profesionalisme guru ini berangkat dari berbagai kelemahan yang terjadi selama implementasi program MGMP bahasa Inggris yang telah berjalan. Dengan demikian, program MGMP tetap menjadi bagian mendasar dari domain dalam model pengembangan profesionalisme guru yang dikembangkan ini. Penelitian ini selanjutnya dipandu melalui pertanyaan-pertanyaan berikut: (1) Mengapa program MGMP bahasa Inggris yang telah berjalan selama ini kurang efektif dalam meningkatkan kemampuan dan keterampilan guru-guru bahasa Inggris dalam melakukan praktik pembelajaran?; (2) Model pengembangan profesionalisme guru bahasa Inggris seperti apa yang dapat diimplementasikan secara efektif untuk meningkatkan kualitas praktik pembelajaran bahasa Inggris?; dan (3) Bagaimana efektivitas model tersebut guna meningkatkan kemampuan dan keterampilan guru bahasa Inggris dalam melakukan praktik pembelajaran bahasa Inggris? Alur kerangka pikir dalam penelitian ini secara ringkas dapat diamati pada Gambar 1. 


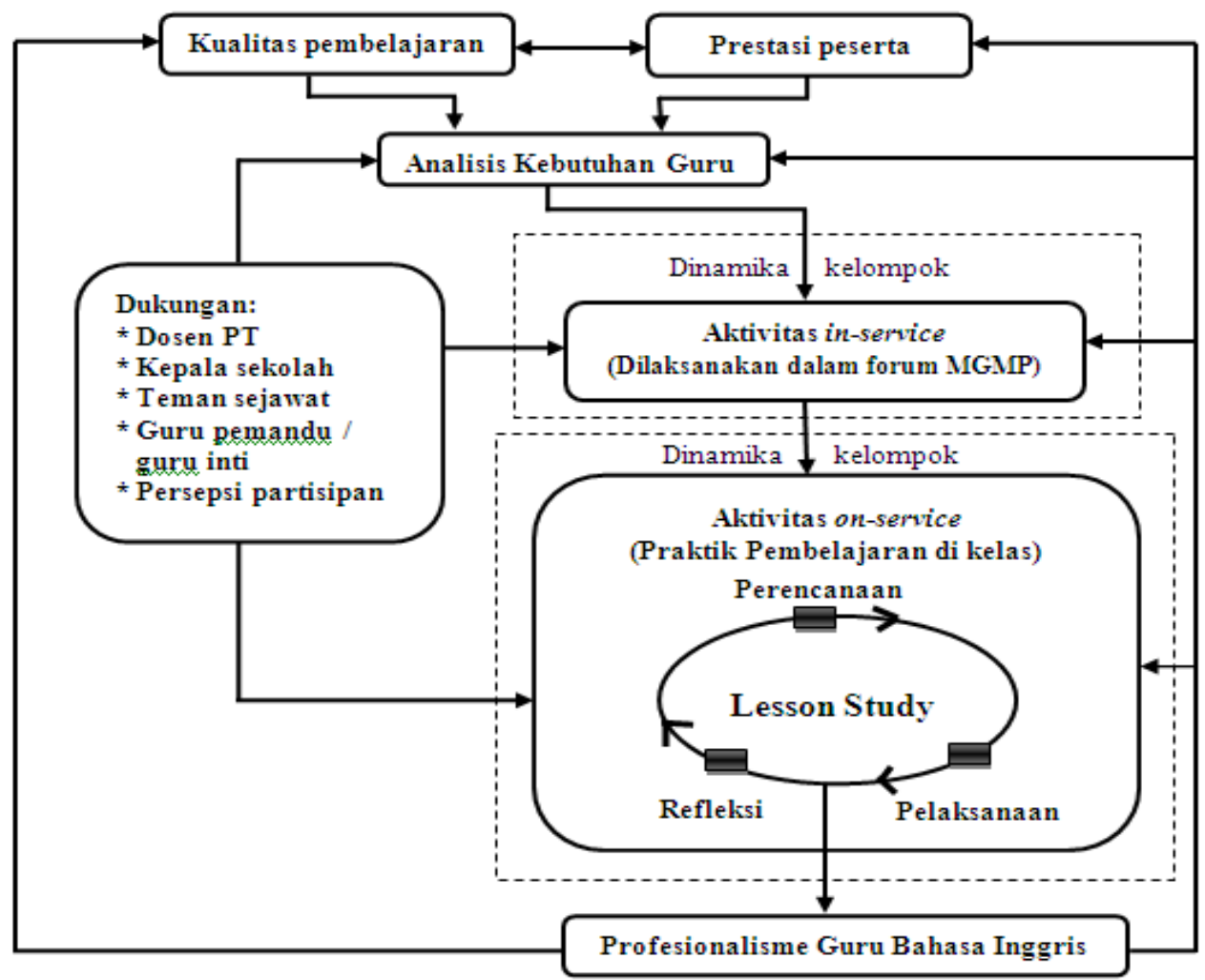

Keterangan:

Sekuensi aktivitas dalam pengembangan profesionalisme guru

Hubungan resiprokal antara dua kondisi

Ranah yang dipengaruhi oleh proses dinamika kelompok

\section{Gambar 1. Alur Kerangka Berpikir}

Pengembangan model PPGBI ini berangkat dari asumsi bahwa kualitas pembelajaran bahasa Inggris yang dilakukan oleh guru akan sangat mempengaruhi prestasi peserta didik pada mata pelajaran tersebut. Semakin baik kualitas pembelajaran yang dilakukan guru, maka prestasi peserta didik pun berpeluang semakin baik pula. Model ini dikembangkan tidak hanya terbatas untuk membekali kemampuan, keterampilan, dan sikap guru bahasa Inggris pada tataran konseptual atau teoretis, tetapi lebih menekankan pada membekali kemampuan, keterampilan, dan sikap guru bahasa Inggris pada tataran praktis. Guna mencapai kedua tataran tersebut, model PPGBI, seperti tampak pada Gambar 2, pada awalnya hanya merekonstruski berbagai aktivitas dalam empat domain yang berbeda, yaitu domain analisis kebutuhan guru (teachers' need assessment), domain latihan persiapan kerja (aktivitas in-service), domain latihan dalam kerja (aktivitas on- service) dan domein peningkatan profesionalsime guru (outcomes). Keempat domain ini mencerminkan sekuensi aktivitas yang bersifat interaktif untuk menghasilkan dampak yang diinginkan, yaitu terjadinya peningkatan profesionalisme guru dalam melakukan proses pembelajaran. 


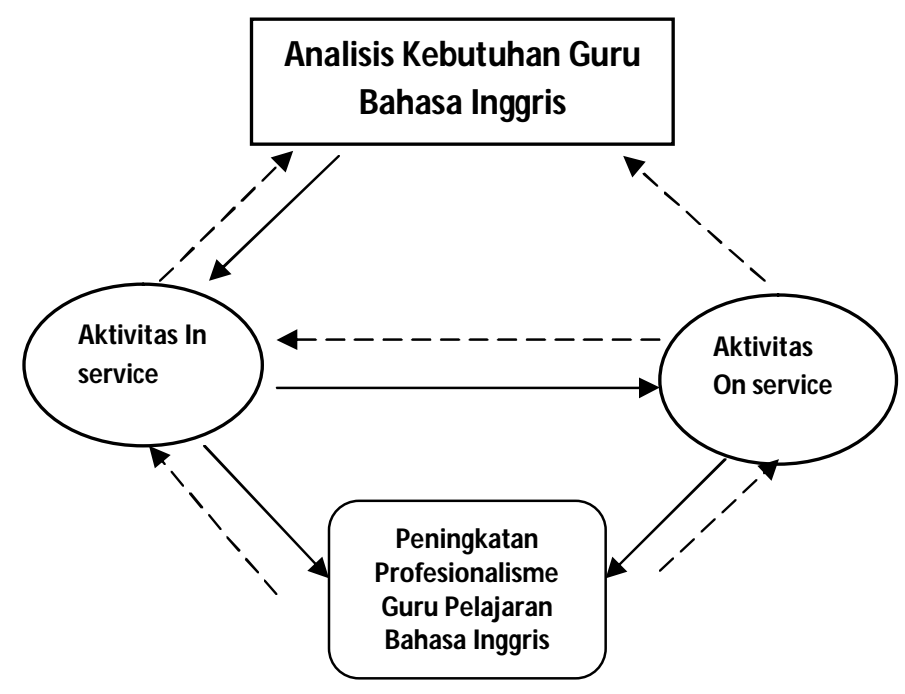

Keterangan gambar:

- - $\rightarrow$ Hasil refleksi dari ...

$\rightarrow$ Hasil pengaruh dari ...

Aktivitas non-training

Aktivitas training
Dampak aktivitas training dan
non training

Gambar 2. Model Konseptual PPGBI

\section{Domain analisis kebutuhan guru bahasa Inggris}

Domain ini dimaksudkan untuk mengidentifikasi materi dan konteks seperti apa yang dibutuhkan oleh guru-guru bahasa Inggris sebagai unit atau subjek yang dikenai implementasi suatu program, agar proses implementasi program pengembangan profesionalisme guru (program MGMP) efektif dalam mencapai tujuan yang diharapkan. Aktivitas-aktivitas yang dilakukan dalam domain analisis kebutuhan guru bahasa Inggris ini adalah (a) mengidentifikasi berbagai kebutuhan yang diperlukan guru-guru bahasa Inggris guna mendukung perbaikan pembelajaran yang dilakukan, (b) mengidentifikasi berbagai permasalahan pembelajaran yang sering dihadapi oleh guru-guru bahasa Inggris, (c) mencari solusi dari berbagai permasalahan pembelajaran bahasa Inggris, (d) mengidentifikasi pengetahuan dan keterampilan apa yang perlu dikembangkan guna mendukung kualitas pembelajaran bahasa Inggris, dan (e) mengidentifikasi kondisi atau konteks seperti apa yang perlu diciptakan atau didesain guna meningkatkan efektivitas pengembangan profesionalisme guruguru bahasa Inggris.

\section{Domain latihan persipan kerja (in-service)}

Domain ini merupakan manifestasi dari treatment atau intervensi guna mengubah kondisi awal dari suatu unit menjadi lebih baik. Domain ini dimaksudkan untuk memberikan pemahaman yang lebih luas kepada guru-guru bahasa Inggris mengenai implementasi kurikulum; pengembangan bahan ajar; model pembelajaran; dan aspek-aspek pendukung proses pembelajaran bahasa Inggris yang lain. Aktivitas-aktivitas yang dilakukan dalam domain ini adalah (a) memberikan feedback terhadap permasalahan pembelajaran yang sering dihadapi oleh guru bahasa Inggris, (b) melakukan diseminasi implementasi kurikulum, pengembangan bahan ajar, model pembelajaran dan aspek- 
aspek pendukung proses pembelajaran bahasa Inggris yang lain, dan (c) memberikan pemahaman kepada guru-guru mengenai bagaimana melakukan perencanaan, pelaksanaan, dan evaluasi proses pembelajaran bahasa Inggris.

\section{Domain latihan dalam kerja (on-service)}

Domain ini juga merupakan manifestasi dari treatment yang dilakukan guna melatih guruguru bahasa Inggris untuk memperbaiki kualitas praktik pembelajaran, sehingga guru-guru mampu melakukan reorientasi proses pembelajaran bahasa Inggris yang aktif, kreatif, efektif, dan menyenangkan bagi siswa. Implementasi berbagai aktivitas dalam domain ini mengikuti filosofi lesson study dimana guru-guru bahasa Inggris secara kolaboratif sebagai berikut: (a) melakukan perencanaan pembelajaran bahasa Inggris (menyusun lesson plan, memilih materi atau bahan ajar, meyiapkan media pembelajaran, menentukan strategi pembelajaran, dan memilih prosedur dan jenis penilaian), (b) melaksanakan pembelajaran bahasa Inggris dimana salah satu guru berperan sebagai guru model dan beberapa guru lain berperan sebagai pengamat, (c) setelah proses pembelajaran selesai, melaksanakan refleksi terhadap proses pembelajaran yang telah dilakukan, (d) berdasarkan hasil refleksi, kemudian melakukan perbaikan lesson plan dan jika perlu menentukan strategi pembelajaran baru untuk melakukan proses pembelajaran ulang, (e) salah satu guru melakukan proses pembelajaran ulang dan guru-guru lain berperan sebagai pengamat (observer), (f) melakukan refleksi kedua terhadap proses pembelajaran yang telah dilakukan secara kolaboratif, dan (g) mendokumentasikan proses pembelajaran yang telah dilakukan.

\section{Domain profesionalisme guru bahasa Inggris (outcomes)}

Domain ini merupakan manifestasi dari result atau dampak implementasi suatu program pelatihan terhadap kinerja guru. Domain ini mengacu pada terjadinya peningkatan profesionalisme guru-guru bahasa Inggris sebagai dampak dari implementasi tiga domain sebelumnya. Indikator peningkatan profesionalisme guru adalah (a) peningkatan pemahaman guru-guru bahasa Inggris mengenai subtansi bahasa Inggris sebagai mata pelajaran, (b) peningkatan pemahaman guru-guru bahasa Inggris mengenai berbagai aspek pedagogis, dan (c) peningkatan kemampuan guru-guru bahasa Inggris dalam menyajikan proses pembelajaran bahasa Inggris yang inovatif, kreatif, efektif, dan menarik bagi peserta didik.

Konsep model di atas pada dasarnya dikembangkan berangkat dari the Interconnected Model of Teacher Professional Growth (IMTPG). IMTPG dikembangkan secara khusus untuk meningkatkan profesionalisme guru-guru IPA, sedangkan karakteristik mata pelajaran IPA berbeda dengan karakteristik mata pelajaran bahasa Inggris. Mata pelajaran IPA lebih banyak menekankan pada aspek inquiry, dimana peran guru lebih banyak membimbing peserta didik. Sebaliknya mata pelajaran bahasa Inggris lebih banyak menekankan pada aspek modeling, dimana peran guru lebih banyak memberikan model/contoh komunikasi dalam bahasa Inggris yang harus ditiru oleh peserta didik (Clarke \& Hollingsworth, 2002). Kedua aspek ini tentu saja menuntut keterampilan relatif berbeda antara guru mata pelajaran IPA dan mata pelajaran bahasa Inggris.

Oleh karena itu, pengembangan pengetahuan, keterampilan, dan sikap yang perlu dimiliki oleh guru-guru kedua mata palajaran itu pun relatif berbeda. Selain itu, ada kelemahan lain yang diidentifikasi dari IMTPG tersebut, yaitu model tersebut lebih menekankan pada aktivitas training sebagai upaya meningkatkan profesionalisme guru IPA. Model itu kurang memperhatikan faktorfaktor non-training, misalnya model tersebut tidak berupaya melakukan analisis kebutuhan guru sebelum melakukan proses training; tidak melihat dukungan iklim dan kondisi kerja untuk 
memperkuat dampak training; dan tidak menekankan pentingnya dinamika kelompok antarguru pada saat dan setelah implementasi training. Faktor-faktor non-training ini diyakini dapat mempengaruhi keefektifan model dalam mencapai tujuan yang telah ditentukan.

Guna mengetahui sejauhmana efektivitas model PPGBI ini dalam mencapai tujuan yang diharapkan, model ini selanjutnya diimplementasikan di lapangan dan sekaligus dievaluasi mengikuti lima tahapan evaluasi Guskey (2000:79) dengan sedikit modifikasi. Lima tahapan evaluasi itu adalah (1) evaluasi mengenai persepsi para guru (teachers' perception) terhadap model PPGBI; (2) evaluasi mengenai terjadinya perubahan pengetahuan, keterampilan dan sikap yang diperoleh setiap guru (teachears' learning); (3) evaluasi mengenai bentuk dukungan iklim dan kondisi kerja terhadap setiap partisipan untuk berubah (climate and working condition for change); (4) evaluasi mengenai perilaku para guru dalam mengaplikasikan pengetahuan dan keterampilan ke dalam kinerjanya (teachers' use of new knowledge and skills); dan (5) evaluasi mengenai perubahan praktik pembelajaran setelah guru-guru berpartisipasi dalam implementasi model PPGBI (teachers' practice outcomes). Kelima tingkatan evaluasi ini bersifat hirarkis yang dimulai dari variabel yang bersifat sederhana ke variabel yang bersifat lebih kompleks.

\section{METODOLOGI}

Penelitian ini adalah sebuah penelitian pengembangan (research and development) yang bertujuan untuk mengembangkan sebuah model pengembangan profesionalisme guru pelajaran bahasa Inggris. Prosedur pengembangan yang dilakukan dalam penelitian ini mengikuti langkahlangkah yang dikemukan oleh Borg dan Gall (1983:775) yang meliputi empat langkah utama pelaksanaan penelitian pengembangan, yaitu (1) studi pendahuluan; (2) pengembangan prototipe; (3) uji lapangan; dan (4) diseminasi produk hasil pengembangan. Subjek coba penelitian ini adalah guru-guru bahasa Inggris yang tergabung dalam program MGMP bahasa Inggris; peserta didik yang diajar oleh guru-guru bahasa Inggris itu; dan kepala sekolah di empat Sekolah Menengah Atas (SMA) negeri dan swasta di kabupaten Sragen, Jawa Tengah.

Empat sekolah itu dipilih secara purposif untuk membedakan kategori sekolah maju, sedang, dan kurang di kabupaten tersebut. Kategori sekolah maju, sedang, dan kurang dilihat dari beberapa indikator, yaitu input peserta didik saat masuk ke sekolah itu; ketersediaan sumber belajar di sekolah (misalnya buku pegangan peserta didik, internet, dan sebagainya); ketersediaan sarana prasarana pendukung pembelajaran yang tersedia (laboratorium bahasa, perpustakaan, komputer untuk menunjang proses pembelajaran, LCD, dan sebagainya); dan dukungan orang tua terhadap penyelenggaraan proses pembelajaran (kesiapan dan kesediaan dana yang diberikan orang tua untuk penyelenggaraan proses pembelajaran). Data dikumpulkan melalui teknik angket, wawancara, dan observasi. Data kemudian dianalisis secara kualitatif guna mengetahui efektivitas model PPGBI dalam mencapai tujuan yang diharapkan, yaitu terjadinya peningkatan profesionalisme guru bahasa Inggris.

\section{HASIL DAN PEMBAHASAN}

Hasil penelitian disajikan dalam dua bagian, yaitu hasil penelitian (1) tentang implementasi program MGMP bahasa Inggris, dan (2) tentang model pengembangan profesionalisme guru bahasa Inggris. Pada bagian pertama, penelitian tentang implementasi program MGMP bahasa Inggris pada dasarnya berupaya mengevaluasi dan kemudian mendeskripsikan berbagai kelemahan dan ketidakefektifan implementasi program tersebut dalam mencapai tujuan yang diharapkan. Selain itu juga dimaksudkan untuk mengidentifikasi berbagai kebutuhan guru bahasa Inggris untuk mampu 
mengelola proses pembelajaran bahasa Inggris yang lebih baik. Berdasarkan kelemahan implementasi program MGMP bahasa Inggris yang ditemukan, kemudian dikembangkan model PPGBI yang hasilnya disajikan pada bagian kedua dalam penelitian ini.

\section{Implementasi Program MGMP Bahasa Inggris}

Implementasi program MGMP bahasa Inggris yang telah berjalan selama ini, diidentifikasi masih terdapat beberapa kelemahan. Kelemahan itu diantaranya adalah (1) belum ada aktivitas program MGMP yang menghendaki peserta untuk melakukan sharing tentang berbagai masalah pembelajaran dan mencari solusi yang tepat; (2) peserta cenderung bersikap pasif selama mengikuti berbagai aktivitas program MGMP; (3) narasumber program MGMP sering kurang qualified sebagai penyampai materi yang dibutuhkan dalam rangka memperbaiki praktik pembelajaran bahasa Inggris; (4) tidak adanya tindak lanjut setelah pertemuan program MGMP diimplementasikan; dan (5) program MGMP tidak dilaksanakan secara teratur dalam waktu tertentu. Cuplikan pendapat partisipan mengenai kelemahan implementasi program MGMP disampaikan oleh Guru 2 berikut:

Saya melihat banyak (kekurangan dalam program MGMP bahasa Inggris), misalnya kurangnya komunikasi antaranggota MGMP; kurangnya informasi dan panduan yang lebih detail dari pihak pengurus MGMP dalam menyediakan pembicara/instruktur yang berkompeten; kurangnya fasilitas yang mendukung di sekolah. Kompleks pokoknya; narasumber program MGMP sering kurang qualified sebagai penyampai materi yang dibutuhkan dalam rangka memperbaiki praktik pembelajaran di kelas; dan aktivitas program MGMP tidak pernah meminta peserta untuk melakukan sharing tentang berbagai masalah pembelajaran dan mencari solusi yang tepat (Interview, 28 Juli 2010).

Identifikasi secara kuantitatif menunjukkan ada 32\% partisipan program MGMP menyatakan tidak pernah, 52\% menyatakan jarang, dan hanya $16 \%$ partisipan menyatakan cukup sering bahwa aktivitas program MGMP meminta partisipan untuk mengidentifikasi kesulitan belajar siswa dan mencari solusi secara kolaboratif. Dengan demikian, dapat disebutkan bahwa berbagai aktivitas program MGMP bahasa Inggris selama ini masih berkutat pada hal-hal yang bersifat teknis dan belum menyentuh hal-hal yang bersifat subtantif, yaitu aktivitas untuk mengembangkan kualitas pembelajaran.

Guru-guru peserta program MGMP pada dasarnya telah cukup baik dalam menguasai materi program. Salah satu contoh penguasaan itu adalah penggunaan ungkapan formal/informal dalam bahasa Inggris. Lebih lanjut Guru 1 menyatakan bahwa:

... bagaimana memilih ungkapan formal/informal dalam bahasa Inggris. Tentu saja ungkapan formal/informal itu sangat dipengaruhi aspek budaya. Formal di sini belum tentu diterima oleh pembicara asli bahasa Inggris. Ya, kita ingat bahasa adalah sangat terikat dengan budaya penutur asli bahasa itu kan? (Interview, 21 Juni 2010).

Namun demikian, guru-guru belum banyak menerapkan materi itu kedalam praktik pembelajaran yang dilakukan. Hasil observasi menunjukkan bahwa kemampuan guru untuk berkomunikasi lisan cukup lancar, tetapi pilihan kosa kata kadang-kadang kurang tepat (Observasi, 26 Juni 2010). Dengan kata lain, pada tataran teori, pengetahuan guru-guru bahasa Inggris setelah berpartisipasi 
dalam program MGMP diidentifikasi sudah cukup baik. Tetapi pada tataran praktik, guru-guru belum banyak mengaplikasikan pengetahuan dan keterampilan itu kedalam proses pembelajaran yang dilakukan. Deskripsi ini memperkuat temuan penelitian yang dilakukan oleh para peneliti sebelumnya bahwa program pengembangan profesionalisme guru selama ini masih sebatas meningkatkan pengetahuan dan kepercayaan guru, tetapi belum mampu mengubah secara signifikan praktik pembelajaran yang dilakukan.

Hasil analisis terhadap kebutuhan guru ditemukan pula bahwa ada beberapa hal yang dibutuhkan oleh guru-guru bahasa Inggris dalam rangka menciptakan proses pembelajaran bahasa Inggris yang lebih baik. Variasi kebutuhan itu dibedakan kebutuhan menyangkut kompetensi pedagogis dan kompetensi profesional. Kebutuhan guru bahasa Inggris pada aspek pedagogis diidentifikasi (1) keterampilan dalam mengelola interaksi kelas, terutama keterampilan dalam memicu dan memelihara keterlibatan siswa dalam proses pembelajaran; (2) keterampilan dalam melaksanakan kegiatan pembelajaran bahasa Inggris dengan menggunakan media yang sesuai dengan tujuan, kondisi siswa, dan tuntutan situasi belajar; (3) keterampilan dalam melaksanakan proses pembelajaran bahasa Inggris dengan mengintegrasikan kegiatan yang dapat membentuk dampak pengiring berupa kecakapan hidup (life skill); (4) keterampilan untuk merencanakan kegiatan yang dapat menyiapkan fisik dan mental siswa untuk memulai belajar; dan (5) keterampilan dalam menangani pertanyaan dan respon siswa selama proses pembelajaran berlangsung. Sedangkan kebutuhan guru pada aspek profesional yang paling menonjol adalah kemampuan khusus dalam mendemonstrasikan pembelajaran bahasa Inggris dengan mengintegrasikan komunikasi lisan dan tulis yang didukung dengan penguasaan unsur-unsur bahasa Inggris, seperti pronunciation, intonation, dan grammar secara tepat.

Berangkat dari temuan di atas, model program pengembangan profesionalisme guru bahasa Inggris berbasis program MGMP ini selanjutnya dilakukan tidak hanya untuk memperluas pengetahuan dan kepercayaan guru semata, tetapi juga bagaimana meningkatkan keterampilan guru secara nyata dalam melakukan praktik pembelajaran bahasa Inggris. Desain program perlu mengintegrasikan aktivitas training dan non-training agar efektivitas program dalam mencapai tujuan dapat dioptimalkan. Aktivitas training dimaksudkan untuk memfasilitasi guru-guru bahasa Inggris dalam mengembangkan kompetensi profesional maupun pedagogis, sehingga wawasan dan kompetensi guru dapat meningkat lebih baik. Sedangkan aktivitas non-training dilakukan sebagai katalisator bagi guru-guru untuk berpartisipasi aktif dalam program itu dan kemudian menerapkan materi program kedalam kinerja yang dilakukan. Aktivitas non-training itu dapat berupa dukungan iklim dan kondisi kerja di sekolah; dan juga penerapan prinsip-prinsip dinamika kelompok dengan baik. Aspek non-training ini diidentifikasi belum dilakukan dalam berbagai program pengembangan profesionalisme guru yang telah berjalan selama ini.

\section{Model PPGBI dan Efektivitasnya}

Hasil pengamatan terhadap praktik pembelajaran yang dilakukan oleh guru-guru bahasa Inggris pada waktu sebelum implementasi model PPGBI diidentifikasi dilakukan dengan tidak banyak memperhatikan variasi kebutuhan dan kondisi siswa saat mengikuti proses pembelajaran. Hal ini ditunjukkan dengan beberapa fakta bahwa sebelum implementasi model PPGBI (1) guru-guru sering tidak mendesain kegiatan yang dimaksudkan untuk menyiapkan fisik dan mental siswa guna memulai belajar; (2) kegiatan pembelajaran sering kurang sesuai dengan tujuan pembelajaran, kebutuhan siswa, perubahan situasi yang dihadapi, dan lingkungan; (3) proses pembelajaran belum banyak menggunakan alat bantu (media) pembelajaran yang sesuai dengan tujuan, kondisi siswa, dan 
tuntutan situasi serta lingkungan (konteks pembelajaran); dan (4) variasi kegiatan pembelajaran belum banyak menonjolkan aktivitas yang berbasis pada individu, kelompok atau klasikal yang perlu dilakukan untuk memenuhi perbedaan individual siswa dan/atau membentuk dampak pengiring berupa kecakapan hidup (life skills).

Sebelum implementasi model PPGBI diketahui bahwa banyak guru yang sering bekerja secara individual dan terisolasi dengan guru-guru lain. Berkaitan dengan ini Guru 2 menyatakan "... ketika mengajar ya (guru-guru) lebih mengandalkan kemampuan masing-masing guru" (Interview, 28 Juli 2010). Tampaknya setiap guru sibuk dengan urusan masing-masing. Perilaku ini telah mengakibatkan terjadinya 'persaingan' tidak sehat diantara guru; ada perasaan tidak aman dalam bekerja; proses pembelajaran tidak dapat berkembang lebih baik; dan kurang adanya keinginan untuk berbagi gagasan (sharing idea) antarguru yang mampu mengarahkan para guru untuk lebih reflektif terhadap proses pembelajaran yang telah dilakukan. Guru 3 secara spesifik menyatakan:

Tidak ada (proses diskusi antarguru bahasa Inggris). Malah tampaknya ada semacam konflik antarguru bahasa Inggris. Tidak ada keterbukaan soal materi yang dimiliki (Interview, 03 Agustus 2010).

Selanjutnya, diidentifikasi pula bahwa tingkat efikasi guru-guru juga masih relatif rendah. Beberapa karakteristik rendahnya tingkat efikasi guru ini adalah sering mengkritik siswa sebagai individu yang kurang kreatif, bodoh, malas, dan suka membuat gaduh; suka mengontrol secara berlebihan perilaku belajar siswa yang mengakibatkan kreativitas siswa seolah-olah terpasung; sering mengabaikan siswa yang memiliki kemampuan belajar lambat; dan suka memberikan hukuman kepada siswa. Fakta empiris seperti diuraikan di atas telah mengakibatkan proses pembelajaran tidak dapat berkembang baik dan akhirnya pencapaian tujuan pembelajaran yang telah ditentukan juga tidak optimal.

Kondisi berbeda ditunjukkan setelah implementasi model PPGBI. Dengan berpartisipasi dalam implementasi model PPGBI ini, partisipan (guru-guru bahasa Inggris) mampu (1) menerapkan mentalitas kerja kolaboratif sebagai upaya untuk memperbaiki proses pembelajaran yang dilakukan setiap hari; (2) menjadi semakin sensitif terhadap permasalahan proses pembelajaran yang dihadapi siswa; dan (3) mampu mengantisipasi berbagai masalah pembelajaran yang mungkin muncul dan dihadapi siswa, sehingga guru mampu menyiapkan dan menentukan solusi antisipatif yang akan diberikan. Hal ini ditunjukkan dengan pernyataan guru 7 sebagai berikut:

Saya merasa surprise karena interaksi siswa pada saat pembelajaran ini di luar dugaan saya, tidak seperti biasanya. Biasanya siswa di sekolah kami sangat sulit apabila diminta presentasi. Waktu sering tersita hanya untuk membentuk kelompokkelompok diskusi. Mereka merasa malu dan takut apabila diminta maju dan berbicara di depan kelas. Tetapi hebatnya saat proses pembelajaran direncanakan bersamasama dan mendapat masukan dari banyak teman, hasilnya di luar dugaan saya. Langkah-langkah pembelajaran didesain secara detail secara kolaboratif dengan banyak memperhatikan kondisi kelas dan kebutuhan belajar siswa. Kita juga memprediksikan masalah-masalah pembelajaran yang mungkin muncul selama proses pembelajaran berlangsung, sehingga kita dapat menyiapkan solusi antisipatif terhadap masalah-masalah yang mungkin muncul. Siswa menjadi lebih aktif dan berani. Oleh karena itu saya merasa perlu ada kelanjutan proses kolaborasi antarguru 
ini. Karena melalui proses ini selain dapat memperbaiki proses pembelajaran, saya juga menjadi sadar akan berbagai kekurangan dari proses pembelajaran yang saya lakukan selama ini (Interview, 03 November 2010).

Selain itu ada perubahan perilaku guru-guru bahasa Inggris, yaitu guru-guru terdorong untuk mau berbicara tentang berbagai isu pembelajaran bahasa Inggris secara intensif dengan sesama guru bahasa Inggris. Dampak lain dari implementasi model PPGBI ini adalah terjadinya perubahan tingkat efikasi guru-guru bahasa Inggris menjadi lebih baik. Senada dengan ini guru menyatakan:

\begin{abstract}
Aktivitas untuk merencanakan, melaksanakan, dan mengobservasi proses pembelajaran ini ternyata perlu dilakukan dalam rangka memperbaiki kualitas pembelajaran. Kita dapat saling berbagi mengenai bagaimana mengelola praktik pembelajaran yang lebih baik. Saya merasa lebih confident lho. Selain itu, kita dapat lebih bersikap reflektif mengenai proses pembelajaran yang kita lakukan (Interview, 20 November 2010).
\end{abstract}

Perubahan tingkat efikasi itu ditandai adanya perilaku guru untuk selalu mengkomunikasikan harapan yang tinggi berkaitan dengan hasil belajar siswa; membantu proses belajar siswa sesuai dengan kondisi dan kebutuhannya; menunjukkan hubungan yang hangat dan bersahabat dengan siswa; memandang siswa yang lambat belajar bukan sebagai sebuah kendala proses pembelajaran; menumbuhkan keyakinan siswa yang lambat belajar bahwa siswa itu dapat berhasil dalam belajar, dan menerapkan sistem manajemen yang tepat untuk mengatasi masalah pembelajaran yang dihadapi. Terjadinya perubahan tingkat efikasi ini telah mengarahkan guru-guru bahasa Inggris mengadopsi berbagai inovasi pembelajaran bahasa Inggris terkini. Hal ini ditunjukkan dengan adanya upaya guru-guru bahasa Inggris untuk mencari bahan ajar dan model-model pembelajaran bahasa Inggris dari internet.

Adanya perubahan kualitas proses pembelajaran, perilaku, sikap, dan tingkat efikasi guruguru bahasa Inggris pada waktu sebelum dan setelah implementasi model PPGBI ini menunjukkan bahwa implementasi model tersebut secara efektif telah mampu meningkatkan profesionalisme guru. Guru-guru menjadi semakin reflektif terhadap proses pemelajaran yang telah dilakukan. Selain itu, implementasi model PPGBI telah mampu memberikan kesempatan guru-guru untuk saling berdiskusi dan bertukar gagasan yang dapat mendorong setiap guru mampu memahami berbagai perspektif belajar siswa. Lebih jauh lagi, model PPGBI telah mampu menciptakan budaya belajar bersama antarguru melalui kondisi nyata yang terjadi di ruang kelas. Terjadinya perubahan profesionalisme guru ini bukanlah peristiwa yang serta merta. Ada rangkaian aktivitas yang perlu dilakukan, sehingga guru-guru bahasa Inggris mampu mengubah perilaku pembelajaran ini menjadi lebih baik.

\title{
PEMBAHASAN
}

Setelah model PPGBI yang dikembangkan ini diujicobakan di lapangan ditemukan beberapa kendala teknis yang mengakibatkan fisibilitas model kadang- kadang sulit diwujudkan. Kendala teknis yang dimaksud lebih mengacu pada prosedur implemetasi model. Revisi model ini, selain dilakukan pada empat sekuensi domain dan mekanisme yang menjadi "pemicu" dilakukannya suatu aktivitas pada suatu domain dalam model tersebut, juga revisi dimaksudkan untuk memperbaiki prosedur implementasi model. 


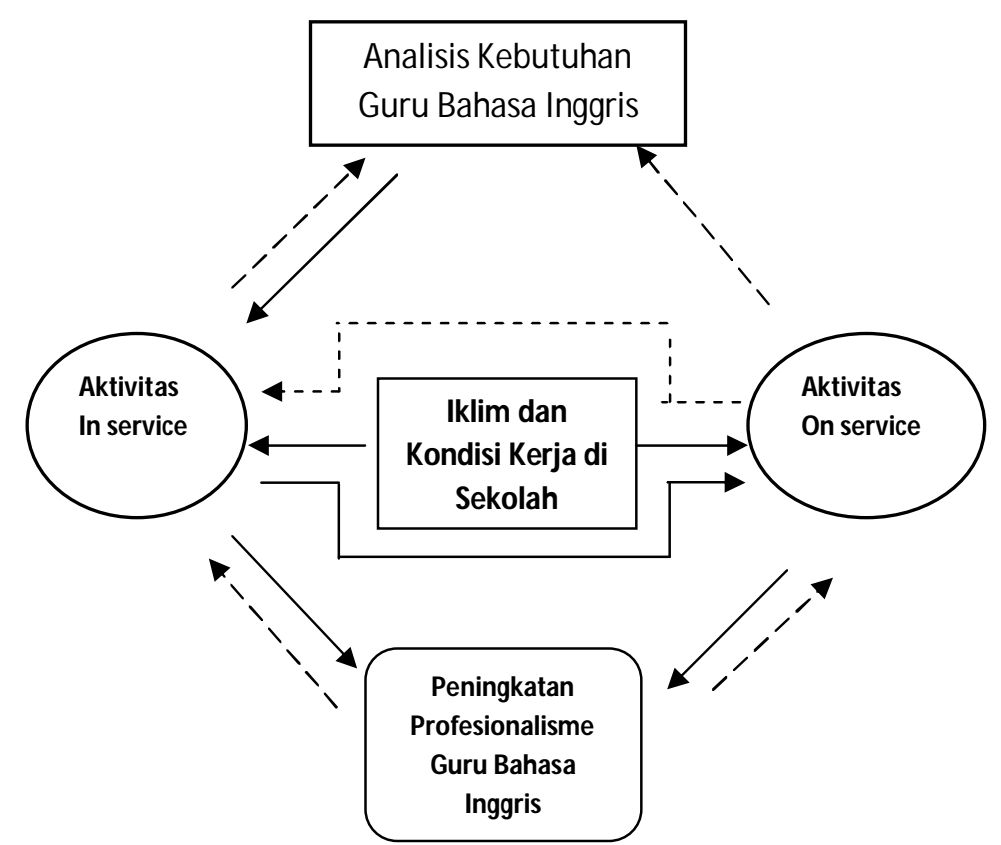

Keterangan gambar:

- - - Hasil refleksi dari ...

Hasil pengaruh dari ...

Aktivitas non-training
Akt Oas training

Dar $\square$ aktivitas training dan non training

Gambar 3: Model PPGBI (sesudah revisi)

Produk akhir berupa model pengembangan profesionalisme guru bahasa Inggris (model PPGBI) ini selanjutnya disajikan seperti gambar 3 di atas. Seperti tampak pada gambar, produk akhir berupa model PPGBI ini terdiri dari lima domain utama, berbeda dengan draft awal yang hanya terdiri dari empat domain. Kelima domain itu adalah (1) Domain Analisis Kebutuhan Guru Bahasa Inggris (English Teachers' Need Assessment / TNA); (2) Domain In-service Activity (IA); (3) Domain Onsevice Activity (OA); (4) Domain Iklim dan Kondisi Kerja di Sekolah; dan (5) Domain Peningkatan Profesionalisme Guru Bahasa Inggris (Outcomes). Hubungan kelima domain tersebut tidak menunjukkan hubungan sekuensial yang kaku, tetapi hubungan kelima domain tersebut lebih bersifat interaktif dan siklis. Bentuk aktivitas dan tujuan dari setiap domain diuraikan pada bagian berikut.

\section{Domain Analisis Kebutuhan Guru (Techers' Need Assessment Domain)}

Tujuan analisis kebutuhan guru adalah mengidentifikasi materi dan konteks seperti apa yang dibutuhkan oleh guru-guru bahasa Inggris, agar kinerja guru-guru bahasa Inggris menjadi lebih baik, maka pelaksanaannya dilakukan dengan cara pemandu MGMP bersama-sama dengan guru-guru bahasa Inggris, yaitu (1) mengidentifikasi berbagai kebutuhan yang diperlukan guru-guru bahasa Inggris guna mendukung proses pembelajaran yang dilakukan oleh guru-guru bahasa Inggris, (2) mengidentifikasi berbagai permasalahan pembelajaran yang sering dihadapi oleh kebanyakan guruguru bahasa Inggris, (3) mencari solusi alternatif dari berbagai permasalahan pembelajaran bahasa Inggris yang telah teridentifikasi, (4) mengidentifikasi pengetahuan dan keterampilan apa yang perlu 
dikembangkan guna mendukung kualitas pembelajaran bahasa Inggris, dan (5) mengidentifikasi kondisi atau konteks seperti apa yang perlu diciptakan guna meningkatkan efektivitas pengembangan profesionalisme guru-guru bahasa Inggris.

\section{Domain Latihan Persiapan Kerja (Domain of In-service Activity)}

Latihan persiapan kerja bertujuan memberikan pemahaman yang lebih luas dan mendalam kepada para guru bahasa Inggris mengenai implementasi kurikulum; pengembangan bahan ajar; model pembelajaran; dan aspek-aspek pendukung proses pembelajaran bahasa Inggris yang lain. Pelaksanaannya dilakukan oleh dosen dari perguruan tinggi sebagai pakar di bidang materi dan pembelajaran bahasa Inggris melalui langkah-langkah berikut, (1) memberikan feedback terhadap permasalahan pembelajaran yang sering dihadapi oleh guru-guru bahasa Inggris, (2) memperluas dan meningkatkan pengetahuan guru-guru bahasa Inggris mengenai materi bahasa Inggris dan pengetahuan mengenai metodologi pembelajaran bahasa Inggris, (3) memberikan konsultasi kepada guru-guru mengenai bagaimana melakukan perencanaan, pelaksanaan, dan evaluasi proses pembelajaran bahasa Inggris, dan (4) melakukan diseminasi praktikpembelajaran bahasa Inggris yang berkualitas melalui aktivitas workshop dan/atau seminar.

\section{Domain Latihan Dalam Keja (Domain of On-service Activity)}

Latihan dalam kerja bertujuan melatih para guru bahasa Inggris untuk memperbaiki kualitas pembelajaran bahasa Inggris, sehingga guru-guru mampu melakukan reorientasi proses pembelajaran bahasa Inggris yang aktif, kreatif, efektif, dan menyenangkan bagi peserta didik. Domain ini dilaksanakan mengkuti filosofi lesson study yang menghendaki guru bekerja secara kolaboratif dalam melakukan sebuah proses pembelajaran. Kegiatan ini dilaksanakan oleh guru-guru bahasa Inggris secara kolaboratif, yaitu dengan (1) melakukan perencanaan pembelajaran bahasa Inggris, seperti menentukan tujuan pembelajaran yang ingin dicapai, (2) menyusun rencana pelaksanaan pembelajaran (lesson plan), (3) memilih materi atau bahan ajar; meyiapkan media pembelajaran; menentukan strategi pembelajaran; dan memilih prosedur dan jenis penilaian, (4) melaksanakan proses pembelajaran bahasa Inggris dimana salah satu guru berperan sebagai guru model dan yang lain sebagai pengamat (observer), dan (5) melaksanakan refleksi terhadap proses pembelajaran yang telah dilakukan guna mengidentifikasi kekuatan dan kelemahan proses pembelajaran yang telah dilakukan (setelah pelajaran selesai).

Selanjutnya, dosen dari perguruan tinggi sebagai pakar di bidang materi dan pembelajaran bahasa Inggris bersama-sama guru pemandu akan (1) melakukan observasi terhadap proses pembelajaran yang direncanakan dan dilakukan secara kolaboratif oleh kelompok guru bahasa Inggris, (2) memberikan feedback terhadap proses pembelajaran yang telah dilakukan oleh kelompok guru bahasa Inggris, dan (3) jika diperlukan, membantu kelompok guru bahasa Inggris dalam melakukan perbaikan lesson plan untuk proses pembelajaran ulang.

Setelah melakukan refleksi terhadap pembelajaran yang dilakukan sebelumnya, guru-guru bahasa Inggris secara kolaboratif akan (1) melakukan perbaikan lesson plan, jika perlu menentukan strategi dan pendekatan pembelajaran bahasa Inggris yang baru, guna melakukan proses pembelajaran ulang, (b) melakukan proses pembelajaran ulang, (c) melakukan refleksi kembali terhadap proses pembelajaran yang telah dilakukan secara kolaboratif pada kesempatan kedua, dan (d) mendokumentasikan proses pembelajaran yang telah dilakukan. 


\section{Domain Iklim dan Kondisi Kerja di Sekolah (Domain of Climate and Working Condition at School)}

Tujuan menganalisis iklim dan kondisi kerja di sekolah adalah untuk menciptakan konteks yang dapat: (i) mendorong partisipan untuk berpartisipasi aktif dalam program pengembangan profesionalisme, dan (ii) mendorong partisipan untuk menerapkan pengetahuan, keterampilan, dan sikap yang diperoleh selama berpartisipasi dalam program pengembangan profesionalisme.

Dalam pelaksanaannya, Kepala sekolah akan berperan dengan cara (i) memberikan dukungan (supporting) terhadap guru, (ii) mengidentifikasi kebutuhan yang mendesak diperlukan guru, kemudian memberikan feedback kebutuhan itu, (iii) memberikan pengaruh yang mampu mengubah perspektif guru, (iv) memprakarsai perencanaan tujuan yang akan dicapai dari suatu kegiatan pengembangan profesionalisme, (v) menumbuhkan komitmen para guru untuk berubah setelah berpartisipasi dalam suatu kegiatan pengembangan profesionalisme, (vi) mengklarifikasi berbagai kendala yang dihadapi oleh guru untuk bisa berubah, (vii) menjelaskan berbagai konsekuensi yang mungkin muncul akibat tindakan yang dilakukan oleh guru, dan (viii) memberikan tindak lanjut (follow up) terhadap kinerja guru setelah berpartisipasi dalam suatu kegiatan pengembangan profesionalisme.

Teman sejawat berperan dalam (a) membantu partisipan (guru-guru bahasa Inggris lainnya) dalam merencanakan proses pembelajaran secara kolaboratif, (b) melakukan observasi proses pembelajaran, (c) memberikan saran dan masukan berkaitan proses pembelajaran yang dilakukan oleh partisipan, dan (d) melakukan evaluasi formal yang dimaksudkan untuk meningkatkan implementasi kurikulum dan teknik instruksional di kelas.

Guru pemandu/guru inti berperan sebagai (a) fasilitator dan narasumber guna menyampaikan atau menyebarluaskanpengetahuan dan keterampilan kepada peserta program MGMP, dan (b) motivator bagi peserta program MGMP untuk mendiskusikan dan mengutarakan ide-ide dalam rangka memperbaiki proses pembelajaran. Dan pengawas sekolah berperan dengan (i) membantu dalam penyusunan dan pelaksanaan program-program MGMP, dan (ii) memberi semangat kepada guruguru untuk ikut serta dalam kegiatan MGMP, dan (iii) memonitor guru-guru dalam menerapkan hasil kegiatan MGMP di kelasnya masing-masing.

\section{Domain Peningkatan Profesionalisme Guru (Outcomes)}

Domain outcomes mengacu pada tingkat profesionalisme guru-guru bahasa Inggris sebagai dampak dari implementasi empat domain sebelumnya. Indikator profesionalisme ini dilihat dari terjadinya perubahan, seperti berikut (Tabel 1).

\section{Tabel 1. Indikator Perubahan Profesionalisme}

\section{Indikator Perubahan Profesionalisme}

1. pemahaman yang lebih baik mengenai sistem lingusitik bahasa Inggris yang meliputi fonologi, tata bahasa, dan wacana;

2. penguasaan prinsip-prinsip dasar pembelajaran bahasa Inggris;

3. kemampuan yang lebih baik dalam mendesain dan melaksanakan rencana pembelajaran yang efektif dan efisien;

4. kemampuan yang lebih baik dalam menciptakan dan menggunakan pendekatan pembelajaran bahasa Inggris; 
Tabel 1. Lanjutan

\section{Indikator Perubahan Profesionalisme}

5. kemampuan yang lebih baik dalam ;memahami dan menggunakan berbagai teknik pembelajaran bahasa Inggris;

6. kemampuan yang lebih baik dalam memberikan feedback kepada siswa agar dapat belajar secara optimal;

7. kemampuan yang lebih baik dalam mendorong setiap siswa untuk berinteraksi dan bekerja sama di kelas;

8. kemampuan yang lebih baik dalam menerapkan prinsip-prinsip manajemen kelas yang baik;

9. kemampuan yang lebih baik dalam menyajikan pembelajaran secara terampil, jelas, dan efektif;

10. kemampuan yang lebih baik dalam mengadaptasi bahan ajar secara kreatif melalui bantuan audio, audio-visual dan alat-alat mekanis lainnya;

11. kemampuan yang lebih baik dalam menggunakan teknik-teknik pengujian yang efektif untuk mengukur hasil belajar siswa;

12. kemampuan yang lebih baik dalam memahami berbagai kebutuhan belajar siswa;

13. ramah terhadap siswa, menunjukkan sikap antusias dalam mengajar, memiliki hubungan dan sikap yang harmonis dengan siswa, dan memiliki rasa humor;

14. bekerja sama secara harmonis dan tulus dengan teman sejawat dalam rangka bertukar pendapat/pikiran, dan berbagai teknik pembelajaran bahasa Inggris.

\section{KESIMPULAN DAN SARAN}

Hasil evaluasi menunjukkan bahwa implementasi model PPGBI mempunyai dampak positif terhadap kualitas proses pembelajaran. Secara rinci dampak implementasi model PPGBI itu adalah (1) pengetahuan tentang materi pelajaran bahasa Inggris meningkat lebih baik; (2) guru-guru mampu merencanakan proses pembelajaran yang dapat mendorong siswa untuk lebih aktif; (3) keterampilan guru dalam melakukan proses pembelajaran bahasa Inggris berubah menjadi lebih baik; (4) efikasi guru dalam melakukan proses pembelajaran bahasa Inggris meningkat lebih baik; (5) guru berkemampuan lebih baik dalam memotivasi siswa agar terlibat secara fisik dan mental selama mengikuti proses pembelajaran; (6) sikap kolegialitas antarguru semakin kuat dalam rangka memperbaiki proses pembelajaran bahasa Inggris; dan (7) guru semakin peka dalam mengamati kesalahan berbahasa Inggris siswa. Model PPGBI yang menghendaki adanya proses inkuiri, belajar bersama, observasi, refleksi, diskusi dan kolaborasi antarguru bahasa Inggris yang dilakukan mengikuti filosofi lesson study ini telah mengarahkan terjadinya peningkatan profesionalisme guru bahasa Inggris.

Implementasi model PPGBI ini ke depan dapat dimanfaatkan oleh pemerintah daerah dalam rangka meningkatkan mutu pendidikan didaerahnya. Implementasi model ini menghendaki adanya kemitraan antara guru-guru bahasa Inggris, guru pemandu, dan dosen dari perguruan tinggi sebagai narasumber yang banyak menguasai materi bahasa Inggris dan metode pembelajaran bahasa Inggris. Proses kemitraan ini tentu saja menghendaki adanya dukungan finansial yang cukup. Dengan demikian, dukungan pemerintah daerah dalam memberikan bantuan dana untuk implementasi model ini pada masa yang akan datang sangat diperlukan. Sesuai dengan prinsip 
otonomi daerah, dukungan ini merupakan salah satu bentuk layanan publik dari pemerintah daerah dalam rangka perbaikan kinerja organisasi sekolah melalui peningkatan kualitas dan profesionalisme guru. Hal ini juga sejalan dengan semangat otonomi daerah bahwa pemerintah daerah perlu meningkatkan layanan publik dalam segala bidang kehidupan, termasuk layanan pendidikan bermutu dalam satuan pendidikan di sekolah.

Salah satu keterbatasan model PPGBI ini adalah model ini belum mencermati dampak model tersebut terhadap peningkatan hasil belajar siswa. Alasannya, untuk melihat dampak implementasi model ini terhadap peningkatan hasil belajar siswa diperlukan pengamatan dalam waktu yang relatif lama. Oleh karena itu, perlu ada pengembangan lebih lanjut mengenai model ini di masa yang akan datang. Pengembangan model ini perlu dilakukan tidak hanya mencermati dampak implementasi model terhadap peningkatan profesionalisme guru, tetapi lebih jauh perlu juga mencermati dampak implementasi model terhadap peningkatan hasil belajar siswa.

\section{REFERENSI}

Borg, W.R., \& Gall, M.D. (1983). Educational research: An introduction (4th ed). Boston: Pearson Education, Inc.

Brown, H.D. (2001). Teaching by principles: An interactive approach to language pedagogy (2nd ed). San Fransisco: Addison Wesley Longman, Inc.

Clarke, D., \& Hollingsworth, H. (2002). Elaborating a model of teacher professional growth. Teaching and Teacher Education, 18, 2002; pg. 947-967.

Depdiknas. (2006a). Pedoman pelaksanaan revitalisasi KKG dan MGMP Jawa Tengah tahun 2006. Jakarta: Ditjen PMPTK \& LPMP Jawa Tengah.

Depdiknas. (2006b). Paket pelatihan 4: Peningkatan mutu pendidikan dasar. Jakarta: Ditjen Dikdasmen.

Jalal, F. (2005) Teachers' quality improvement in Indonesia: New paradigm and milestones. Jakarta: Departemen Pendidikan Nasional.

Guskey, T.R. (2000). Evaluating professional development. California: Corwin Press.

Kikpatrick, D.L. (1996). Evaluating training programs. San Fransisco: Berrett-Koehler Publisher. Sumardi, R. (2009). Problem Profesionalisme Guru dan Mutu Pendidikan. Diambil dari web http://robertsumardi.wordpress.com/2012/02/25/problema-profesionalisme-guru-dan-mutupendidikan-2/. 